\title{
PROBLEMATIKA PENEGAKKAN HUKUM MENGACU PADA UNDANG-UNDANG NOMOR 4 TAHUN 2009 TENTANG PERTAMBANGAN MINERAL DAN BATUBARA
}

\author{
Yahman \\ Fakultas Hukum Universitas Airlangga \\ Jl. Darmawangsa Dalam selatan Surabaya \\ Email: yahmanaldi@yahoo.co.id; yahmanaldi12@gmail.com
}

\begin{abstract}
Law enforcement against illegal mining, minerals and coal in particular have problems in terms of storage seizure of evidence. An actor burdened cost of storage of evidence or known by the term "demorrag" by law enforcement agencies. This condition is not in accordance with the concept of Law No. 8 of 1981 on the Criminal Procedure Code and Government Regulation No. 27 Year 1983 on Guidelines for the Criminal Procedure Code, particularly in relation to the storage of goods confiscated evidence (RUPBASAN) are not sufficiently available. This study found that the application of Law No. 4 of 2009 on Mineral and Coal still not run as expected in actual society and it violates Human Rights (HAM) and is still far from hope for justice seekers.
\end{abstract}

Key words: confiscation, “demorrag”, coal

\begin{abstract}
Abstrak
Penegakkan hukum terhadap illegal mining, khususnya mineral dan batubara mengalami hambatan dalam hal penyimpanan penyitaan barang bukti. Seorang pelaku terbebani biaya penyimpanan barang bukti atau dikenal dengan istilah "demorrag" oleh institusi penegak hukum. Kondisi ini tidak sesuai dengan konsep Undang-Undang Nomor 8 Tahun 1981 tentang KUHAP maupun Peraturan Pemerintah Nomor 27 Tahun 1983 tentang Pedoman Pelaksanaan KUHAP, khususnya terkait dengan tempat penyimpanan barang bukti sitaan (RUPBASAN) yang belum tersedia secara memadai. Penelitian ini menemukan bahwa dalam penerapan Undang-Undang Nomor 4 Tahun 2009 tentang Pertambangan Mineral dan Batubara masih belum berjalan sesuai harapan masyarakat dan dalam pelaksanaannya justru melanggar Hak Asasi Manusia (HAM) serta masih jauh dari harapan bagi pencari keadilan.
\end{abstract}

Kata kunci: penyitaan, demorrag, batubara

\section{Latar Belakang}

Undang-Undang Dasar Negara Republik Indonesia Tahun 1945 mengamanatkan bahwa bumi dan air dan kekayaan alam yang terkandung di dalamnya dikuasai oleh Negara dan dipergunakan untuk kepentingan sebesarbesar bagi kemakmuran rakyat sebagaimana ditegaskan dalam Pasal 33 ayat (3) UndangUndang Dasar 1945. ${ }^{1}$ Mineral dan batubara sebagai kekayaan alam yang terkandung di

1 Ditegaskan bahwa aumi, air dan Kekayaan Alam yang terkandung di dalamnya di kuasai oleh negara untuk kemakmuran rakyat. Filosofinya adalah suatu kehendak negara untuk melindungi alam demi kesejahteraan rakyatnya dari penguasaan-penguasan yang ilegal oleh kelompok tertentu yang menguntungkan bagi kelompoknya atau dirinya sendiri. 
dalam bumi merupakan sumber daya alam sebagai karunia Tuhan yang perlu dilestarikan, pengelolaannya perlu dilakukan seoptimal mungkin, efisien, transparan, berkelanjutan, dan berwawasan lingkungan, serta berkeadilan agar memperoleh manfaat sebesar-besar kemakmuran rakyat secara berkelanjutan.

Perkembangan selanjutnya sesuai Ketetapn MPR Nomor IX/MPR/2001 tentang "Pembaharuan Agraria dan Pengelolaan Sumber Daya Alam". Ditegaskan dalam Pasal 4 TAP MPR Nomor IX/MPR/2001 memuat prinsip-prinsip pembaharuan agraria dan pengelolaan sumber daya alam. Pembaharuan agraria dan pengelolaan sumber daya alam dilaksanakan sesuai dengan prinsip-prinsip sebagai berikut, yaitu:

a) memelihara dan mempertahankan keutuhan Negara Kesatuan Republik Indonesia;

b) menghormati dan menjunjung tinggi hak asasi manusia;

c) menghormati supremasi hukum dengan mengakomodasi keanekaragaman dalam unifikasi hukum;

d) mensejahterakan rakyat, terutama melalui peningkatan kualitas sumber daya manusia Indonesia;

e) mengembangkan demokrasi kepatuhan hukum, transparansi dan optimalisasi partisipasi rakyat;

f) mewujudkan keadilan termasuk kesetaraan gender dalam penguasaan, pemilikan, penggunaan, pemanfaatan, dan pemeliharaan sumber daya alam; g) memelihara keberlanjutan yang dapat memberi manfaat optimal, baik untuk generasi sekarang mpun untuk generasi mendatang dengan tetap memperhatikan daya tampung dan daya dukung lingkungan;

h) melaksanakan fungsi sosial, kelestarian, dan fungsi ekologis sesuai dengan kondisi sosial budaya stempat;

i) meningkatkan keterpaduan dan koordinasi antara sektor pembangunan dan antar daerah dalam pelaksanaan pembaharuan agraria dan pengelolaan sumber daya alam;

j) mengakui menghormati, dan melindungi hak masyarakat hukum adat dan keanekaragaman budaya bangsa dan sumber daya agraria/sumber daya alam;

k) mengupayakan keseimbangan hak dan kewajiban negara, pemerintah (pusat, daerah provinsi, kabupaten/kota, dan desadesa atau yang setingkat), masyarakat dan individu;

1) melaksanakan desentralisasi berupa pembagian kewenangan di tingkat nasional, daerah provinsi, kabupaten/kota, dan desa atau yang setingkat, berdekatan dengan likasi dan pengelolaan sumber daya alam.

Sesuai TAP MPR huruf $\mathrm{j}$ tersebut, maka pembaharuan dan pengelolaan sumber daya alam harus memperhatikan prinsip mengakui, menghormati dan melindungi hak masyarakat setempat dan keanekaragaman budaya bangsa atas sumber daya alam. Sejalan dengan 
diundangkannya Undang-Undang Nomor 4 Tahun 2009 tentang Pertambangan Mineral dan Batubara, perlu dilakukan langkahlangkah konkrit untuk melakukan penataan kembali pengaturan yang berhubungan dengan kegiatan usaha dibidang pertambangan mineral dan batubara, diperlukan adanya regulasi-regulasi pertambangan di antaranya, izin pertambangan, pengendalian, meningkatkan pendapatan masyarakat lokal, menciptakan lapangan pekerjaan untuk kesejahteraan masyarakat di lokasi atau disekitar penambangan.

Usaha-usaha ini dilakukan di maksudkan agar dalam kegiatan usaha pertambangan mineraldanbatubara,tidakmerusaklingkungan hidup disekitar lokasi pertambangan dan ada manfaat bagi masyarakat setempat, sehingga dapat meningkatkan tarap hidup masyarakat yang sejahtera serta dapat menciptakan lapangan pekerjaan untuk mengurangi lajunya pengangguran. Di sisi lain regulasi ini diperlukan, agar terdapat keseimbangan alam di lokasi pertambangan mineral dan batu bara tidak merusak lingkungan yang dapat menimbulkan bencana alam, seperti: tanah longsor, banjir dan lain sebagainya.

Dalam kegiatan pertambangan mineral dan batu bara, diutamakan pemasokan kebutuhan mineral dan batubara untuk kepentingan alam negeri guna menjamin tersedianya mineral dan batubara sebagai bahan baku dan/atau sebagai sumber energi untuk kebutuhan dalam negeri.
Pelaksanaan dan pengendalian kegiatan usaha pertambangan secara berdaya guna, berhasil guna, dan berdaya saing untuk sebesar-besar kesejahteraan rakyat. Berdasarkan Pasal 36 Undang-Undang Nomor 4 Tahun 2009, dalam usaha pertambangan disyaratkan ada 2 (dua) tahap yaitu:

a) IUP (Izi Usaha Pertambangan) eksplorasi meliputi kegiatan penyelidikan umum, eksplorasi, dan studi kelayakan;

b) IUP (Izin Usaha Pertambangan) operasi produksi meliputi kegiatan konstruksi.

Ekplorasi adalah tahap kegiatan usaha pertambangan untuk memperoleh informasi secara tereperinci dan teliti tentang lokasi, bentuk, dimensi, sebaran kualitas sumber daya terukur dari bahan galian, serta informasi mengenai lingkungan sosial dan lingkungan hidup. Tahap ini pengambilan contoh mineral untuk bahan penelitian laboratorium dengn cara pengeboran dan tidak dilakukan dengan cara menggali secara manual oleh tenaga manusia. ${ }^{2}$ Pengangkutan merupakan kegiatan usaha pertambangan untuk memindahkan mmineral dan/atau batubara dari daerah tambang dan atau/tempat pengelolaan dan pemurnian sampai tempat penyerahan, dilanjutkan dengan penjualan hasil pertambangan mineral dan batubara.

Tahap operasi produksi, adalah yang merupakan kegiatan usaha pertambangan meliputi kontruksi, penambangan, pengelolaan, pemurnian, termasuk

2 Nazar Kusmana, Pelaksana Bagian Hukum dan perundang-undangan pada Direktorat Jenderal Mineral, Batu Bara dan Panas Bumi Kementrian ESDM, suatu pendapat yang disampaikan dalam kesaksian pada proses Penyidikan kasus illegal mining. 
pengangkutan dan penjualan serta sarana pengendalian dampak lingkungan sesuai hasil studi kelayakan.

Terkait dengan Ijin Usaha Pertambangan dalam Pasal 37 Peraturan Pemerintah Nomor 23 Tahun 2010 tentang Pelaksanaan Kegiatan Usaha Pertambangan Mineral dan Batubara, ditegaskan ${ }^{3}$ bahwa:

(1) IUP Operasi Produksi khusus sebagaimana dimaksud dalam Pasal 36 huruf a diberikan oleh:

a) Menteri apabila kegiatan pengangkutan dan penjualan dilakukan lintas propinsi dan negara;

b) Gubernur apabila kegiatan pengangkutan dan penjualan dilakukan lintas kabupaten/kota; atau

c) Bupati/walikota apabila kegiatan pengangkutan dan penjualan dalam 1 (satu) kabupaten/kota.

(2) IUP Operasi Produksi khusus sebagaimana dimaksud dalam Pasal 36 huruf $\mathrm{b}$ diberikan oleh:

a) Menteri, apabila komoditas tambang yang akan diolah berasal dari propinsi lain dan/atau lokasi kegiatan pengolahan dan pemurnian berada pada lintas provinsi;

b) Gubernur, apabila komoditas tambang yang akan diolah berasal dari beberapa kabupaten/kota dalam 1 (satu) provinsi dan/atau lokasi kegiatan pengolahan dan pemurnian berada pada lintas kabupaten/kota; atau

c) Bupati/walikota, apabila komoditas tambang yang akan diolah berasal dari 1 (satu) kabupaten/kota dan/ atau lokasi kegiatan pengolahan dan pemurnian berada pada 1 (satu) kabupaten/kota.

(3) Dalam hal komoditas tambang yang akan diolah sebagaimana dimaksud pada ayat (2) berasal dari impor, IUP Operasi Produksi khusus untuk pengolahan dan pemurnian diberikan oleh Menteri.

Berdasarkan uraian di atas, terdapat permasalahan hukum berkaitan pelanggaran tindak pidana di bidang pertambangan batubara. Dengan demikian rumusan masalah pada tulisan ini yaitu:

1. Bagaimana penerapan hukum atas Undang-undang Nomor 4 Tahun 2009, tentang pemberantasan tindak pidana illegal mining yang terjadi belakangan ini?

2. Bagaimana pelaku tindak pidana terhadap illegal mining, khususnya mineral dan batubara tidak terbebani dalam hal penyimpanan penyitaan barang bukti atau "demorrag"?

Tujuan dari tulisan ini ialah untuk menguji dan menganalisis apakah konteks penegakkan hukum di Indonesia menyangkut illegal mining khususnya mineral dan batubara tidak mengalami hambatan dalam penyimpanan

3 Pasal 37 Peraturan Pemerintah Nomor 23 Tahun 2010 tentang Izin Usaha Operasi Produksi Pertambangan, yang wajib dimiliki oleh seseorang atau perusahaan yang melakukan kegiatan pertambangan yang dikeluarkan oleh menteri, gubenur dan bupati sesuai lintas wilayahnya dan kewenangannya. 
penyitaan barang bukti dan pelaku tindak pidana tidak terbebani penyimpanan penyitaan barang bukti atau "demorrag" di masa mendatang.

Manfaat yang diharapkan dari tulisan ini yaitu secara teoritis hasil penelitian ini dapat mengembangkan serta menambah pemahaman di bidang ilmu hukum, khususnya hukum pidana dibidang tindak pidana illegal mining khusnya mineral dan batubara. Hasil penelitian ini diharapkan dapat memberikan masukan pemikiran bagi aparat penegak hukum dan pembuat kebijakan dalam hal tindak pidana di bidang pertambangan khususnya mineral dan batubara dalam penyimpanan penyitaan barang bukti atau “demorrag), sehingga pelaku tindak ini tidak terbebani beaya penyimpanan penyitaan barang bukti atau demorrag.

Tulisan ini merupakan jenis penelitian hukum yang bersifat praktis yaitu dengan melakukan penelitian dan kajian di Derektorat Reseserse Kriminal Khusus Polda Jatim secara komprenhesif tentang penegakkan hukum dibidang tindak pidana illegal minning khususnya mineral dan batubara.Penelitian hukum dalam kaitannya dengan penelitian hukum yang bersifat praktis, sebagaimana ditulis oleh Peter Mahmud Marzuki bahwa, penelitian hukum adalah suatu proses untuk menemukan aturan hukum, prinsip-prinsip hukum, maupun doktrin-doktrin hukum guna menjawab isu hukum yang dihadapi. ${ }^{4}$

Metode pendekatan yang digunakan yaitu pendekatan perundang-undangan (statute approach); pendekatan kasus (case approach); dan pendekatan konsep (conceptual approach). ${ }^{5}$ Pendekatan perundang-undangan dan pendekatan kasus digunakan untuk mengkaji sanksi hukum dalam tindak pidana illegal minning. Sedangkan pendekatan konsep digunakan untuk menganalisis penerapan hukum dalam tindak pidana illegal minning dan problematikanya. Bahan hukum yang telah terkumpul dianalis dengan langkahlangkah sebagai berikut: langkah pertama, menganalisis konsep hukum tentang illegal minning beserta doktrin yang berkembang dalam hukum pidana, sebagai langkah kedua, adalah menganalisis beberapa putusan pengadilan yang terkait dengan penerapan konsep penegakkan hukum dibidang illegal minning.

\section{Pembahasan}

Penanggulangan terhadap peristiwa atau kasus-kasus yang berkaitan dengan illegal mining, menunjukan upaya penindakan terhadap kejahatan di bidang illegal mining dengan menggunakan suatu kebijakan pidana (penal policy). ${ }^{6}$ Menurut Sudarto memberikan suatu definsi tentang "penal policy" dari sudut tujuannya, yakni untuk

4 Peter Mahmud Marzuki, Penelitian Hukum, Prenada Media, Jakarta, 2005, hlm. 35.

5 Ibid.

6 Dalam konteks penegakan hukum diperlukan suatu kebijakan atau "penal policy", lihat dalam Barda Nawawi Arief, Masalah Penegakan Hukum dan Kebijakan Penanggulangan Kejahatan, Bandung, Citra Aditya Bakti, 2001, hlm. 73. 
mewujudkan peraturan perundang-undangan pidana yang sesuai dengan keadaan dan situasi pada suatu waktu dan untuk masa-masa yang akan datang. ${ }^{7}$ Dalam hal kebijakan pidana dalam arti penal law enforcement policy meliputi beberapa tahap, di antaranya tahap formulasi, tahap aplikasi dan tahap eksekusi, akan tetapi dalam kaitannya ini, pembahasan akan difokuskan pada tahap aplikasi atas penerapan Undang-Undang Nomor 4 Tahun 2009, tentang pemberantasan tindak pidana illegal mining, yang terjadi belakangan ini.

Dalam hal law enforcement perdilan pidana (penyidikan kasus illegal mining) merujuk pada operasionalisasi peraturan perundang-undangan oleh aparat penegak hukum pidana dalam upaya menanggulangi dan memberantas kejahatan di bidang illegal minning. Operasionalisasai itu dilakukan melalui proses peradilan pidana (criminal justice proces $)^{8}$, yaitu diperlukan suatu proses dari kerja aparat penegak hukum dalam memeriksa pelaku yang diduga melakukan kejahatan untuk memastikan bersalah tidaknya pelaku yang bersangkutan secara hukum. Pada tahap pemeriksaan ini, merupakan suatu proses, yaitu tahap penyelidikan, penyidikan, penuntutan, sampai pada tahap pada penentuan hukuman atau penjatuhan vonis hakim.

Menurut Romli Atmasasmita ${ }^{9}$, memberikan suatu pengertian istilah perbedaan criminal justice proces dengan criminal justice system, yaitu pada setiap tahap dari suatu putusan yang menghadapkan seseorang pelaku ke pada tahapan proses yang membawanya kepada penentuan pidana baginya. Sedangkan yang dimaksud dengan criminal justice system yaitu interkoneksi antara putusan dari setiap instansi yang terlibat dalam proses peradilan pidana.

Mencermati pendapat tersebut, dalam criminal justice system sebagimana diterangkan dalam Undang-Undang Nomor 8 Tahun 1981, tentang KUHAP, suatu sistem peradilan pidana sebagai aparat penegak hukum, meliputi: Polri selaku penyidik/ Penyidik Pegawai Negeri Sipil Tertentu, Jaksa selaku Penuntut dan Hakim selaku pemutus terhadap seseorang yang melakukan perbuatan pidana dalam arti sempit. Penegak hukum dalam arti luas yaitu: Polri selaku penyidik/ Penyidik Pegawai Negeri Sipil tertentu, Jaksa selaku Penuntut dan Hakim selaku pemutus, ditambah Advokad dan Lembaga Pemasyarakatan. Lembaga Pemasyarakatan sebagai lembaga yang menjalankan dan membina serta mengawasi terpidana yang sedang dan selama menjalankan vonis hakim.

Dari interkoneksi sistem penegak hukum dalam arti sempit maupun dalam arti luas tersebut, tentunya harapan yang dikehendaki dapat berjalan dengan baik sesuai yang dicita-

7 Sudarto, Hukum Pidana dan Perkembangan Masyarakat; Kajian terhadap Pembaharuan Hukum Pidana, Sinar Baru, Bandung, 1983, hlm. 109.

8 Hagan, sebagaimana disitir oleh Romli Atmasasmita, Sistem Peradilan Pidana: Perspektif Eksistensialisme dan Abolisionisme, Bina Cipta, Bandung, 1996, hlm. 14.

9 Ibid. 
citakan hukum dan keadilan. Akan tetapi dalam prakteknya harapan tersebut tidak berjalan sebagaimana mestinya. Suatu contoh kasus yang terjadi di Lembaga Pemasyarakatan Bojonegoro, dalam kasus lukir terpidana Kasiyem yang divonis hakim selama 7 (tujuh) bulan dalam dua kasus pupuk bersubsidi yang sudah mempunyai kekuatan hukum tetap, Kasiyem tidak mau menjalankan pidana, melakukan penukaran dengan pihak Karni dengan imbalan uang sebesar Rp. 22.000.000,(dua puluh dua juta) rupiah, dengan melibatkan aparat penegak hukum yaitu: Atmari petugas Lembaga Permasyarakatan Bojonegoro, Hasnomo Pengacara Karni, Widodo Priyono Staf Kejaksaan Negeri Bojonegoro dan Angga seorang makelar kasus penukaran narapidana terjadi tanggal 27 Desember 2010. Empat pelaku ( Atmari, Hasnomo, Widodo dan Angga) saat ini menjalani proses persidangan, sementara Kasiyem dan Karni dalam proses penyidikan di Polres Bojonegoro dan ditetapkan sebagai tersangka. ${ }^{10}$

Daricontohkasustersebutmenggambarkan bahwa, aparat penegak hukum mengalami suatu penurunan mentalitas moral dalam law enforcement untuk menegakkan hukum yang dicita-citakan oleh masyarakat. Criminal justice system tidak berjalan sebagaimana mestinya, hal demikian menunjukan kurangnya pengawasan dari institusi di atasnya dalam penegakkan hukum dan keadilan. Di samping itu sumber daya manusianya yang kurang disiplin dalam menjalankan tugas yang diembannya, faktor yang paling dominan dalam peristiwa ini dalah kurangnya kesejahteraan bagi mereka.

Menurut teori Lawrence M. Friedman ${ }^{11}$, menyatakan dalam mempelajari dan membahas tentang hukum dan sistem hukum ada 3 (tiga) pokok pikiran penegakan hukum dapat berjalan dengan baik meliputi, yaitu :

1. Struktur, yaitu keseluruhan institusiinstitusi hukum yang ada beserta pelaksanannya atau aparat hukumnya berjalan dengan baik. Di antaranya pelaksana hukum Polri dengan Polisinya, Kejaksaan dengan Jaksanya, Pengadilan dengan hakimnya;

2. Substansinya, keseluruhan aturan-aturan hukum, norma hukum, asas-asas hukum, yang tertulis maupun tidak tertulis, termasuk putusan pengadilan;

3. Kultur hukum, yaitu kepercayaankepercayaan, kebiasaan-kebiasaan, cara bertindak, cara berpikir oleh masyarakat maupun para penegak hukum, tentang hukum dan berbagai fenomena yang berkaitan dengan hukum.

Pemikirann Friedman, ditinjau dari struktur hukum, aparat penegak hukum dalam arti luas tersebut meliputi yaitu, Polri, Kejaksaan, Pengadilan, KPK dan lembaga Permasyaratan, para Advokat atau pengacara serta lembaga-lembaga penegak 
hukum lainnya. Lembaga-lembaga yang ada ini dalam penegakkah hukum diharapkan bertindak secara profesional dan proporsional sesuai aturan hukum yang berlaku secara adil dan transparan.

Ditinjau dari sustansinya, yaitu diharapkan dalam penegakkan hukum tidak terjadi penyalahgunaan wewenang (abuse of power) oleh apara penegak hukum. Dengan demikian tujuan hukum yang dicita-citakan akan berjalan sesuai harapan masyarakat pencari kedilan. Dalam praktek peradilan, khususnya di Indonesia proses penyelesaian sengketa tidak efektif dan efesien memerlukan waktu yang panjang, mahal tidak terjamin adanya kepastian hukum, meskipun ada azas beracara di pengadilan itu "sederhana, cepat dan biaya ringan" hanya hiasan belaka. ${ }^{12}$

Kemudian pemikiran Firedman, ditinjau dari kultur hukum, dewasa ini praktek penegakkan hukum, baik dalam tingkat proses penyidikan, proses penuntutan maupun proses peradilan serta proses pemidanaan dalam lembaga pemasyarakatan terjadi penyelewengan hukum yang seharusnya dijunjung tinggi. Persoalan yang demikian ini sehingga dalam semua tingkatan proses penegakkan hukum yang dilaksanakan oleh para aparat penegak hukum terjadi penurunan kepercayaan masyarakat, bahkan yang lebih ekstrem kepercayaan masyarakat telah hilang akibat perilaku hukum.

Merujuk pada sudut kulturnya, budaya yang sudah mendarah daging dalam kehidupan masyarakat Indonesia selama ini, apabila mengalami persoalan hukum tidak mau repot-repot dengan memilih jalan pintas yang dihubungkan dengan uang, belum ada kesadaran hukum masyarakat itu sendiri maupun aparatnya, suatu budaya yang tertanam akibat dari penjajahan Belanda sampai dengan masa Orde Baru.

Berkaitan peradilan pidana dewasa ini mengalami pergeseran, menurut Basuki Rekso Wibowo $^{13}$ mengemukakan bahwa paradigma beracara di pengadilan telah mengalami pergeseran yang memprihatinkan. Idialisme berperkara untuk menegakan keadilan yang substansial, telah bergeser menjadi pergulatan kesempatan dan kekuatan untuk saling mengalahkan (to bethe winner, not the losser). Dengan demikian dalam praktek penegakkan hukum telah terjadi pergeseran paradigma tersebut maka keadilan direduksi menjadi persoalan kalah dan menang. ${ }^{14}$

Menurut pemikiran Friedman. ${ }^{15}$, "prilaku hukum" disebutkan adalah:

12 Yahman, Karakteristik Wanprestasi dan Tindak Pidana Penipuan yang Lahir dari Hubungan Kontraktual, Prestasi Pustaka, Jakarta, 2011, hlm. 87.

13 Basuki Rekso Wibowo, Menyelesaikan Sengketa Bisnis di Luar Pengadilan, Makalah disampaikan pada Pengukuhan Guru Besar dalam Bidang Ilmu Hukum, Fakultas Hukum Universitas Airlangga, Surabaya, 17 Desember 2005, hlm. 4.

14 Ibid.

15 Achmad Ali, Menguak Teori Hukum (Legal Theory) dan Teori Peradilan (Judicialprudence), Jakarta, Prenada Media Group, 2009, hlm. 146. 
1. Adanya perbuatan hukum (rechtshandeling), yaitu suatu perbuatan yang dilakukan oleh subjek hukum, yang berakibat hukum, akibat hukum itu telah dikehendaki oleh pelaku hukum;

2. Adanya perbuatan melawan hukum (onrechtmatige daad), yaitu perbuatanperbuatan yang dilakukan oleh subjek hukum, yang berakibat hukum yang tidak dikehendaki oleh pelaku hukum tersebut

Ketiga teori pemikiran dari Friedman tersebut, apabila dalam penegakkan hukum dijalankan secara benar, profesional dan proporsional maka hukum yang berlaku di Indonesia tersebut akan berjalan dengan baik, tercipta rasa keadilan dan manfaat hukum yang dibuat dapat diharapkan oleh masyarakat. Akan tetapi dalam kenyataannya sangat penegakan hukum bertolak belakang dari tujuan hukum dan tujuan keadilan.

Untuk menghindari penyelewengan dan penyalahgunaan, berkaitan dengan penyelidikan, penyidikan, penuntutan dan persidangan diperlukan kontrol kualitas kerja yang obyektif, berfungsi untuk memastikan profesionalisme aparat sekaligus untuk mengontrol kinerja aparat menurut standar kerja yang telah ditentukan. Sistem reward and punishment, berfungsi sebagai stimulus agar aparat produktif dalam bekerja. ${ }^{16}$

Dalam penegakkan hukum yang berkaitan dengan kasus illegal mining selama ini mengalami suatu kenyataan atau fenomena yang tidak sesuai dengan asas beracara dipemgadilan, "sederhana, cepat dan biaya ringan" masih jauh dari harapan. Suatu contok kasus penangangan Illegal Minning yang ditangani oleh Kepolisian Daerah Jawa Timur, terkait meneral, batu bara dan batu mangaan. Dalam kurun waktu 2010 sampai tahun 2012 terjadi 17 (tujuh belas) kasus meneral batu bara dan batu mangan. ${ }^{17}$ Penegakkan hukum terhadap illegal mining, khususnya kasus meneral batu bara dan batu mangaan. Ada pepatah mengatakan "sudah jatuh ketiban tangga", yang artinya adalah seseorang sudah ditetapkan tersangka dan menghadapi persoalan hukum atas pelanggaran yang dilakukannya, juga masih menghadapi kemungkinan kerugian yang tidak sedikit berupa "demorit", suatu istilah biaya yang dikeluarkan dalam sewa gudang terhadap barang yang disita oleh penyidik.

Demorit dilakukan mengingat tempat penyimpanan barang bukti yang mudah terbakar atau berbahaya, belum ada tempat penyimpanan barang sitaan sebagaiman diamanatkan oleh Undang-Undang Nomor 8 Tahun 1981 dan Peraturan Pemerintah Nomor 27 Tahun 1983, yang menyatakan barang bukti sitaan disimpan di RUPBASAN (Rumah Penyimpanan Barang Sitaan). Dalam pratiknya RUPBASAN di masing-masing wilayah belum memadai bahkan belum

16 Jacky Uly dan Bernard L. Tanya, Money Laundering, Laros, Surabaya, 2009, hlm. 82.

17 Sumber data: Ditreskrim Kepolisian Daerah Jawa Timur dalam melakukan penyidikan atas kasus illegal mining. 
ada, sehingga kesulitan dalam melakukan penyimpaan barang sitaan. Sehingga dengan demikian seseorang yang melakukan pelanggaran illegal mining terbebani biaya penyimpanan barang.

Dalam praktik penegakan hukum dalam kasus illegal mining, khususnya kasus meniral batu bara dan batu mangaan, ada 2 (dua) cara yaitu:

1. Barang yang disita disimpan di gudang dengan mengeluarkan biaya penyimpanan selama proses penyidikan yang dikenal dengan istilah "demorit";

2. Barang yang disita dititipkan kepada pemegang atau pemilik barang yang disita selama proses penyidikan.

Suatu fenomena yang dialami oleh seseorang yang melakukan pelanggaran di bidang illegal mining, suatu perlakuan yang seharusnya tidak perlu terjadi jika instrumen hukumnya telah tersedia dalam hal penegakkan hukum. Hal ini diterima oleh pelaku pelanggaran illegal mining, khususnya pelanggaran meneral batu bara dan batu mangaan semata-mata tidak ingin mengalami kerugian yang lebih besar, jika barang yang disita mengalami kerusakkan atau mengalami penyusutan. Oleh karena itu seseorang yang sedang menghadpi persoalan hukum dalam kasus ini tidak ada pilihan lain kecuali menerima perlakuan yang seharusnya tidak perlu terjadi, jika sarana dan prasanan hukum memadai dalam menegakkan hukum khususnya kasus illegal mining. ${ }^{18}$

Merujuk pemikiran Lawrence M. Friedman dalam mencermati persoalan tersebut di atas, dalam penegakkan hukum tidak terlepas dari pemikirannya yaitu, penegakkan hukum dapat berjalan baik apabila struktur hukumnya jelas, sarananya menunjang, petugasnya bekerja dengan baik sesuai yang diharapkan oleh masyarakat. Pemikiran Friedman tidak terbantahkan dalam praktik penegakkan hukum khususnya bidang illegal mining.

Pasal 44 Ayat (1) dan Ayat (2) KUHAP ditegaskan bahwa, benda sitaan disimpan dalam rumah penyimpanan benda sitaan negara, kemudian penyimpanan benda sitaan dilaksanakan dengan sebaik-baiknya dan tanggungjawab pada pejabat yang berwenang sesuai tingkat pemeriksaan dalam proses peradilan dan benda tersebut dilarang untuk dipergunakan oleh siapa pun. Filosofi yang terkandung dalam Pasal 44 KUHAP bahwa konskwensinya adalah instansi yang melakukan penyitanan, wajib menjaga keutuhan maupun kerusakan barang sitaan yang dijadikan objek barang bukti selama proses peradilan berlangsung dan pertanggungjawaban atas keutuhan maupun kerusakkan barang sitaan menjadi tanggung jawab masing-masing sesuai tingkat pemeriksaan sampai tingkat peradilan.

18 Suatu contoh kasus yang di tangani oleh Ditreskrim (sekarang Ditreskrimsus) Polda Jatim dalam pelanggaran di bidang illegal mining, khususnya kasus batubara dan batu mangan dari Nusa Tenggara Timur yang dijual dan dieksport melalui pelabuhan Tanjung Perak Surabaya secara umum pelanggaran yang terjadi dalam pengangkuatan batu mangan tidak dilengkapi oleh dokumen yang resmi atau dokumen pengangkutannya dipalsukan, semata-mata untuk mencari keuntungan sebesar-besarnya tanpa mempedulikan kelestarian lingkungan dan kondisi masyarakat setempat. 
Kemudian dalam penjelasan Pasal 44 Ayat (1) KUHAP dinyatakan bahwa, selama belum ada rumah penyimpanan benda sitaan negara di tempat yang bersangkutan, penyimpanan benda sitaan tersebut dapat dilakukan di kantor kepolisian negara Republik Indonesia, dikantor kejaksaan negeri, kantor pengadilan negeri, di gedung bank pemerintah dan dalam keadaan memaksa di tempat penyimpanan lain atau di tetap ditempat semula benda sitaan itu di sita. ${ }^{19}$

Rumah penyimpanan benda sitaan yang dikenal dengan istilah RUPBASAN ditegaskan dalam Pasal 26 Peraturan Pemerintah Republik Indonesia Nomor 27 Tahun 1983 tentang Pelaksaan KUHAP bahwa, Ayat (1) Di tiap Ibu Kota Kabupaten/Kotamadya dibentuk RUPBASAN oleh Menteri; Ayat (2) Apabila dipandang perlu Menteri dapat membentuk RUPBASAN di luar tempat sebagaimana dimaksud dalam Ayat (1) yang merupakan cabang RUPBASAN; Ayat (3) Kepala cabang RUPBASAN diangkat dan diberhentikan oleh Menteri. $^{20}$

Selanjutnya terkait dengan benda sitaan, sesuai Keputusan Menteri Kehakiman Republik Indonesia Nomor: M.01.PW.07.03 Tahun 1982 tentang Pedoman Pelaksanaan Kitab Undang-Undang Hukum Acara Pidana (KUHAP) tanggal 4 Pebruari 1982 di Bidang Penyidikan, ditegaskan bahwa: benda yang dapat disita yaitu, tindakan penyitaan yang berupa pengambilalihan atau menyimpan di bawah penguasaan Penyidik dapat dilakukan terhadap: benda bergerak dan benda tidak bergerak; benda berwujud atau benda tidak berwujud; atau dapat pula terhadap benda yang berada dalam sitaan perkara perdata, sebagaimana Pasal 39 Ayat (2) KUHAP.

Aturan selanjutnya sesuai Keputusan Menteri Kehakiman Republik Indonesia Nomor: M.14.PW.07.03 Tahun 1983 tanggal 10 Desember 1983 tentang Tambahan Pedoman Pelaksanaan Kitab Undang-Undang Hukum Acara Pidana (KUHAP), dalam lampiran Keputusan Menerti Kehakiman Republik Indonesia Sub ke 2 terkait dengan benda sitaan ditegaskan bahwa, dalam hal sesuatu benda sitaan dipinjamkan kepada orang dari mana barang itu disita, tidak diperlukan izin dari ketua pengadilan negeri, tetapi ada kewajiban untuk melaporkan hal itu kepada ketua pengadilan negeri dalam bentuk tembusan. Namun jika akan mengubah status dari benda sitaan negara (dijual, dimusnahkan dan sebagainya), harus mendapat izin dari ketua pengadilan negeri. Dalam hal terjadi perbedaan pendapat antara penyidik dan penuntut umum mengen ai status benda sitaan tersebut pada saat perkara itu dilimpahkan dari penyidik kepada penuntut umum, maka putusan akhir ada pada instansi yang

19 Penjelasan Pasal 44 Ayat (1) KUHAP memberikan penegasan penyimpanan benda sitaan dapat disimpan di tempat semula benda itu disita, sehingga dalam penyitaan terhadap benda yang mudah rusak atau mudah terbakar, menguap disimpan atau dititipkan kepada orang yang menguasai benda yang disita selama proses peradilan berlangsung.

20 Lihat Peraturan Pemerintah Nomor 27 Tahun 1983 Bab IX tentang Rumah Penyimpanan Benda Sitaan Negara atau dikenal dengan Istilah RUPBASAN diatur dalam Pasal 26 sampai dengan Pasal 34. 
bertanggung jawab secara yuridis atas benda sitaan itu setelah hal tersebut dikonsultasikan secara sungguh-sungguh antara penyidik dan penuntut umum.

Mencermati aturan tersebut dikaitkan dengan penegakkan hukum, khususnya kasus batu bara dan mangaan, tempat penyimpanan benda sitaan (RUPBASAN) belum tersedia tempat atau sarana yang ada di masing-masing Propinsi/Kabupaten dan Kota. Sehingga penyimpanan barang sitaan terhadap barang bukti batu bara dan batu mangaan yang sedang di tangani oleh penyidik Kepolisian Daerah Jawa Timur, mengambil suatu kebijakan hukum atas tindakan atas benda sitaan dalam penyimpanannya.

Berkenaan dengan kebijakan hukum (penal policy). Sudarto memberikan suatu definsi penal policy dari sudut "tujuannya", yakni untuk mewujudkan peraturan perundangundangan pidana yang sesuai dengan keadaan dan situasi pada suatu waktu dan untuk masa-masa yang akan datang. Reorientasi dan reformulasi kebijakan yang demikian ke depan sangat diperlukan. Dengan tujuan untuk melakukan pembaharuan hukum pidana (penal reform), khususnya penyelesaian dalam tindak pidana illegal mining yang merupakan bagian dari kebijakan hukum pidana (penal policy). Sehingga rasa keadilan akan tercapai sesuai harapan masyarakat. ${ }^{21}$

Bila persoalan ini dibiarkan berlarut-larut, dan aturan yang ada dalam Undang-Undang
Nomor 4 Tahun 2009 tentang Mineral dan Batubara, Peraturan Pemerintah Nomor 23 Tahun 2010 tentang Pelaksanaan Usaha Pertambangan Mineral dan Batubara akan melahirkan suatu kebijakan yang melahirkan perundang-undangan yang buruk. Undangundang ini lahir menggantikan UndangUndang Nomor 11 Tahun 1967 tentang Ketentuan-Ketentuan Pokok Pertambangan (Lembaran Negara Republik Indonesia Tahun 1967 Nomor 22, Tambahan Lembaran Negara Republik Indonesia Nomor 2831). Dalam undang-undang ini tidak mengatur secara jelas penyimpanan terhadap benda sitaan dalam tahap penyidikan, penuntutan dan peradilan dan mengacu pada ketentuan yang berlaku dalam KUHAP.

Tindakan kebijakan hukum yang menyimpan barang sitaan, khususnya benda sitaan batubara dan batu mangaan dalam proses penyidikan secara tidak langsung telah terjadi suatu pelanggaran hukum dan pelanggaran Hak Asasi Manusia (HAM), dalam tatanan hukum di Indonesia telah diamanatkan sebagaimana diatur dalam Undang-Undang Nomor 39 Tahun 1999 (Lembaran Negara Tahun 1999 Nomor 165, Tambahan Lembaran Negara Tahun 1999 Nomor 3885, Pasal 1 ke 6 menyatakan, ${ }^{22}$ bahwa:

$$
\begin{aligned}
& \text { "Pelanggaran hak asasi manusia } \\
& \text { adalah setiap perbuatan seseorang } \\
& \text { atau kelompok orang termasuk }
\end{aligned}
$$


aparat negara baik disengaja maupun tidak disengaja atau kelalaian yang secara melawan hukum mengurangi, menghalangi, membatasi, dan atau mencabut hak asasi manusia seseorang atau kelompok orang yang dijamin oleh oleh undangundang ini, dan tidak mendapatkan, atau dikhawatirkan tidak akan memperoleh penyelesaian hukum yang adil dan benar, berdasarkan mekanisme hukum yang berlaku".

Filosofi dan dasar pertimbangan UndangUndang Nomor: 39 Tahun 1999 tentang Hak Asasi Manusia adalah:

a) Manusia sebagai makhluh Tuhan Yang Maha Esa dianugerahi hak asasi untuk menjamin keberadaan harkat dan martabat kemuliaan dirinya serta keharmonisan lingkungannya;

b) Hak Asasi Manusia (HAM) merupakan hak dasar yang secara kodrati melekat pada diri manusia, bersifat universal dan langgeng, sehingga harus dilindungi, dihormati, dipertahankan dan tidak boleh diabaikan, dikurangi atau dirampas oleh oleh siapun;

c) Untuk melaksanakan Deklarasi Universal tentang Hak Asasi Manusia (HAM) Instrumen internasional lainnya mengenai Hak Asasi Manusia (HAM) yang telah diratifikasi Indonesia.

Berkenaan dengan pertimbangan pada butir b Undang-undang HAM tersebut, sangat jelas bahwa Hak Asasi Manusia (HAM) harus dilindungi termasuk dalam penegakan hukum pelanggaran di bidang illegal mining. Tidak boleh diabaikan walaupun seseorang melakukan pelanggaran hukum, namun hak-hak dan martabatnya tetap dijamin, dihormati dan dilindungi, dipertahankan, tidak boleh dirampas oleh siapapun termasuk negara maupun para penegak hukum.

Dalam bidang pertambangan melalui Undang-Undang Nomor 11 Tahun 1967 tentang Pokok-Pokok Pertambangan yang diubah dengan Undang-Undang Nomor 4 Tahun 2009 tentang Pertambangan Mineral dan Batubara, secara tegas memberikan kewenangan bagi negara untuk menguasai sumber-sumber daya alam. Berkenaan dengan pertambangan Mineral dan Batubara, dalam kehidupan masyarakat sering terjadi konflik, hal ini muncul tidak begitu saja melainkan melalui beberapa tahapan. Kinflik tersebut mulai dengan keluhan sebagai pemicu munculnya antipati yang membuat seseorang atau kelompok merasa diperlakukan tidak adil. Timbulnya konflik-konflik yang terjadi itu akan meningkat perlu adanya penyelesaian terhadap konflik-konflik tersebut, dan membutuhkan pihak ketiga.

Menurut Nyoman Nurjaya ${ }^{23}$ menyatakan bahwa, secara umum konflik terjadi dalam masyarakat besumbe dari persolan-persolan sebagai berikut: 
1) Penguasaan, pemanfaatan dan distribusi sumber daya alam yang me njadi pendukung kehidupan (natural resouece control and distribution);

2) Ekspansi batas wilayah kehidupan suatu kelompok masyarakat (teritoriality expantion);

3) Kegaiatan ekonomi masyarakat (economic actives); dan

4) Kepadatan penduduk (density of population).

Konflik merupakan fenomena sosial yang tidak dapat dipisahkan (inherent) dari kehidupan manusia, apalagi dalam masyarakat bercorak multicultural, tidak mungkin dihindari atau diabaikan dalam kehidupan bersama. $^{24}$

Berkaitan fenomena konflik dalam masyarakat Nader dan Todd ${ }^{25}$, menyatakan bahwa pada dasarnya konflik-konflik yang terjadi dalam masyarakat melalui tahapan (concflict stages) di antaranyanya sebagai berikut:

1) The grievance or preconflict, refer to a circumstance or condation whitch one person (or group) perciives to be unjust, and the grounds for resentment or complaint;

2) The conflict stage, therefore is diadic. Is it not the offender's move: he may escalate, or attempt to deescalet thorugh coercion of, or negotition of a settlement whit, the aggrieved party;

3) The dispute state, result from escalation of the conflict by making matter public.

Oleh karena terjadinya konflik dalam masyarakat tidak terjadi secara tiba-tiba, akan tetapi melalui beberapa tahapan. Mulai adanya keluhan ketidaksenangan, kebencian yang membuat seseorang atau kelompok merasa menadapat perlakukan tidak adil.

Tanggung jawab pemerintah dalam menuntaskan kasus illegal mining tidak terlepas adanya muatan politik yang membonceng berbagai permasalahan dalam kehidupan rakyat, dapat dilihat persoalan yang dihadapi oleh rakyat di Sumbawa, sering kali berujung pada kebijakan tidak populer yang diragukan obyektifitasnya. contoh kasus, tarik menarik penyelesaian kasus illegal mining Olat Labaong yang dilakukan oleh pemerintah daerah dengan alasan menjaga kondusifitas daerah, sulit dipercaya dan terlalu berlebihan karena terkesan mengada-ada. ${ }^{26}$

Dipandang dari sudut kepentingan aturan, illegal mining tergolong pelanggaran berat, dengan ancaman hukuman penjara di atas 5 tahun dan denda kurang lebih Rp10 milyar. Sedangkan dari sudut pandang lingkungan, illegal mining tergolong kejahatan kemanusiaan yang tidak boleh mendapat perlakuan khusus dalam bentuk toleransi,

24 Laura Nader and Harry F. Todd JR, The Disputing Process Law In Ten societies, Columbia University Press, New York, 1978, hlm. 14-15.

25

26 Sumba News, http://labaong.sumbawanews.com/pemerintahlalaidalammenuntaskankasus-kasusillegalmininglabaong, diakses 14 Januari 2013 pukul $15.00 \mathrm{WIB}$. 
karena zat kimia air raksa (Mercury) yang digunakan pada proses pemisahan pasir emas tanpa dilakukan pengawasan yang ketat dalam tekhnis penambangan, hal ini jika dibiarkan sama dengan suatu tindakan pembunuhan massal secara perlahan-lahan. Oleh karena itu berangkat dari pemahaman tersebut, maka illegaal mining tidak ubahnya suatu persolan yang menakutkan perlu cermati dan diwaspadai semua pihak khususnya pemerintah mempunyai kewajiban memperhatikan dan mengawasi secara serius demi keselamatan umat manusia terkait dengan penambangan ini.

Dapat dibayangkan, dalam kurun waktu relatif singkat kurang lebih 3 (tiga) bulan aktifitas illegal mining di satu titik yakni, Bukit Olat Labaong Kecamatan Lape sebaran alat pemisah pasir emas yang disebut gelondongan jumlahnya tidak kurang dari 400 unit. Di dalam satu unitnya perhari menghabiskan sedikitnya 2 (dua) kilogram mercury. Artinya selama tiga bulan seluruh gelondongan yang ada telah menghabiskan 72.000 kilogram mercury, yang rata-rata limbahnya dibuang begitu saja diatas permukaan tanah. Akibat tidak adanya pengawasan, penertiban dan pembinaan dari pihak pemerintah, maka resiko keselamatan pelaku illegal mining tidak ada jaminan, resiko konflik selalu terbuka dan resiko kerusakan alam pasti terjadi, khususnya illegal mining Olat Labaong telah terjadi sejumlah kasus diantaranya orang hilang, orang meninggal kekurangan oksigen, orang meninggal karena tertimbun reruntuhan tanah kesemuanya dibungkus rapi oleh pelaku penambangan lainnya agar tidak terekspos keluar. Akibat ketatnya pengamanan oleh kelompokkelompok penguasa Labaong yang disebut tim panitia, membuat pihak kepolisian, pemerintah dan wartawan kesulitan mengakses informasi dari wilayah tersebut. ${ }^{27}$

Jika dicermati keadaan seperti ini, pemerintah seharusnya melakukan langkahlangkah konkrtit untuk mengantisipasi persolan yang akan terjadi, tidak menutup kemungkinan akan menjadi bom waktu bagi Kabupaten Sumbawa.

Contoh kasus lainnya, yaitu pengangkuatan atau penjualan menieral logam mangan yang terjadi dilokasi penambangan di Antambua oleh salah satu perusahaan pertambangan, dalam kegiatan eksplorasi penambangan yang sembarangan tanpa ada pengawasan yang ketat oleh pemerintah daerah, maka tidak menutup kemungkinan akan terjadi kerusakan lingkungan hidup di sekitar lokasi pertambangan. Pasal 4 Undang-Undang Nomor 4 Tahun 1982 tentang KetentuanKetentuan Pokok Pengelolaan Lingkungan Hidup Pengelolaan Lingkungan Hidup, mengandung asas dan tujuan sebagai berikut:

1. Tercapainya keselarasan hubungan antar manusia dengan lingkungan hidup sebagi tujuan membangun manusia indonesia seutuhnya;

2. Terkendalinya pemnfaatan sumber daya secara bijaksana; 
3. Terwujudnya manusia indonesia sebagai pembina lingkungan hidup;

4. Terlaksananya pembangunan berwawasan lingkungan untuk kepentingan generasi sekarang dan mendatang;

5. Terlindunginya negara terhadap dampak kegiatan diluar wilayah negara yang menyebabkan kerusakan dan pencemaran lingkungan.

Kita lihat kasus tambang mamer di Timur Tengah Utara, merupakan salah satu daya tarik tersendiri terdapat kandungan emas, marmer, tembaga, mangan dan sebagainaya ada di perut bumi Plobamora. Kandungan yang ada di Pulau Timor, Alor, Lembata, Flores mulai dari ujung timur sam pai Manggarai Barat, kaya akan bahan meneral. Deposit marmer di Timur Tengah Utara dan mangan di Manggarai, sudah nampak jelas, bahkan sudah dalam tahap eksploitasi.

Warga Reo dalam kegiatan eksploitasi mangan, pernah terjadi konflik antara pemerintah dan masyarakat, akan tetapi pemerintah tidak begitu menghiraukan. Akan tetapi tanpa disadari sudah berjalan lama, mangan Reo secara diam-diam di bawa ke Pulau Jawa khususnya Surabaya untuk kebutuhan perindustrian masyarakat Surabaya dan sekitarnya, bahkan dieksport ke beberapa Negara. Dalam kegiatan penambangan oleh investor PT. Arumbai di Serise, Dampek, Lambaleda terjadi kerusakan lingkungan diteitik penambangan, oleh investor tidak pernah mereklamasi lingkungan di sekitar titik mangan pasca eksploitasi. Beberapa pekan silam, kemudian DPRD Manggarai "baru" tersentak kaget dan mempersoalkan kehadiran PT.Arumbai yang mengesploitasi mangan Reo. ${ }^{28}$

Dari pihak dinas Pertambangan Propinsi Nusa Tenggara Timur menyebutkan eksploitasi mangan Reo, setiap bula tidak kuran mengirim 100 ton mangan ke pulau Jawa. Setiap pengiriman mangan pemerintah setempat mendapatkan royalty dengan ketentuan $10 \%$ harga mangan di pasaran dunia. Harga pasaran dunia Rp. 2,5 juta per kilogram. Dapat dibayangkan berapa jumlah banyak mangan dikirim ke pulau Jawa dan pemerintah Kabupaten Manggarai tidak mendapatkan apa-apa. Dari pihak PT. Arumbai dalan kegiatan tidak ada kejujuran berkaitan dengan penanbangan mangan, yang dikirim ke pulau Jawa, khususnya Surabaya.

Kasus mangan menjadi suatu pelajaran bagi daerah lain. Izin yang dikeluarkan adalaheksplorasi akan tetapi kegiatan dilapangan yang terjadi adalah eksploitasi. Dengan berkaca pada aktivitas penambangan yang hampir selalu menim bulkan protes warga, maka model tambang rakyat patut dipertimbangkan sebagai model pengelolaan sumber kekayaan alam daerah. Dengan model ini rakyat merasa memiliki dan merasakan kepentingan langsung dari hasil tambang di daerahnya. Juga akan tum buh kesadaran

28 Adonia Ivone Laturette, Hak Ulayat dalam Hukum Tanah Nasional (Ringkasan Disertasi), UNAIR, Surabaya, 2011, hlm. 87. 
untuk memelihara dan merehabilitasi lingkungannya. ${ }^{29}$

Dari rangkaian pelanggaran-pelanggaran hukum atas pengangkutan batu mangan dari wilayah Nusa Tenggara Timur ke pulau Jawa, khususnya Surabaya yang dilakukan penyidikan oleh Direktorat Reserse Kepolisian Daerah Jawa Timur maupun Polres Tanjung Perak Surabaya secara umum dokumen pengangkutan dipalsukan atau menggunakan dokumen palsu. Seharusnya dokumen menyertai pengangkutan batu mangan dapat dikeluarkan oleh pemerintah setempat. Penomena ini menggambarkan kurangnya pengawasan yang dilakukan oleh pemerintah setempat, maupun adanya unsur kesengajaan yang dilakukan oleh investor. Hal ini dilakukan oleh pihak investor untuk mengejar keuntungan usahanya tanpa memikirkan kondisi maupun lingkungan di lokasi penambangan.

Kasus pengangkutan batu mangan yang tidak dilengkapi dokumen resmi dengan modus yang dilakukan oleh dua perusahaan, yaitu PT. Gema Eximindo dan CV Utama Sentosa dengan menunjuk direktur kedua perusahaan dari Warga Negara Indonesia. Mengingat pemilik ke dua perusahaan tersebut sebagai Warga Negara Korea, kedua perusahaan tersebut bergerak di bidang pertambangan batu mangan melakukan eksplorasi di Belu, dan Timor Tengah, hingga pertengahan Juli 2010, Polri menahan 11 (sebelas) kontainer batu mangan milik kedua perusahaan tersebut di depo Surabaya di Pelabuhan Temabaga, Tanjung Perak. Ditemukan Surat Keputusan Menteri Mineral dan Energi Nomor: 1607/K/ MEM/2004 tentang Ijin Usaha batu mangan yang diduga palsu dan tidak terdaftar serta tercatat di kementerian Enegi sumber daya menieral. ${ }^{30}$ Dalam putusan Pengadilan Negeri Surabaya pelakunya telah divonis penjara selama 18 (delapan belas) bulan dinyatakan terbukti tidak memiliki dokumen yang sah.

Secara umum pelanggaran-pelanggaran yang dilakukan oleh pihak investor yaitu, pengangkutan dan penjualan logam mangan tanpa dilengkapi dengan izin usaha (IUP) dan operasi produksi khusus serta usaha penambangan tanpa ijin sebagaimana dimaksud dalam Pasal 161, 158 Jo. Pasal Ayat (1) huruf b Jo. Pasal 37 huruf c Jo. Pasal 105 Ayat (1) Undang-Undang RI Nomor 4 Tahun 2009 tentang Meneral dan Batubara Jo. Pasal 37 Peraturan Pemerintah Nomor 23 Tahun 2010 tentang Pelaksanaan Usaha Pertambangan Mineral dan Batubara.

\section{Simpulan}

Penegakkan hukum terkait dengan illegal mining, khususnya menyangkut mineral dan batubara mengalami suatu kendala atau hambatan yaitu, dalam hal penyitaan barang bukti mengalami kesulitan dalam penyimpanannya oleh penyidik, penuntut umum maupun hakim selama proses peradilan 
bagi pelaku pelangaran di bidang illegal mining, khususnya mineral dan batubara. Seorang investor atau pelaku pelanggaran illegal mining terbebani biaya penyimpanan barang bukti atau dikenal dengan istilah "demorit" oleh isntitusi penegak hukum, mulai dari tahap penyidikan, penuntutan sampai proses pemeriksaan pengadilan. Hal ini terjadi karena institusi penegak hukum tidak mempunyai tempat penyimpanan barang bukti yang disita, walaupun amanat dalam Undang-Undang Nomor 8 Tahun 1981 tentang KUHAP maupun Peraturan Pemerintah Nomor 27 Tahun 1983 telah ditegaskan adanya tempat penyimpana barang sitaan (RUPBASAN), dalam kenyataannya RUPBASAN sebagai penyimpanan barang bukti sitaan belum tersedia secara menyeluruh.
Kondisi seperti ini tentunya, pertama telah terjadi pelanggar Hak Asasi Manusia (HAM) sebagaimana dietgaskan dalam Pasal Pasal 1 ke 6 Undang-Undang Nomor 39 Tahun 1999 (Lembaran Negara Tahun 1999 Nomor 165, Tambahan Lembaran Negara Tahun 1999 Nomor 3885. Kedua terkait dalam konteks penegakan hukum terhadap Undang-Undang Nomor: 4 Tahun 2009 telah mengalami hambatan, sehingga penerapannya tidak mencerminkan rasa keadilan bagi para pelaku pelanggaran di bidang illegal mining. Dengan demikian diharapkan Undang-Undang Nomor 4 Tahun 2009 perlu dilakukan amandemen atau perubahan, agar undang-undang ini berjalan efektif dan bermanfaat bagi masyarakat serta tercapai rasa keadilan.

\section{DAFTAR PUSTAKA}

\section{Buku}

Achmad Ali, 2009, Menguak Teori Hukum

(Legal Theory) dan Teori Peradilan

(Judicialprudence), Prenada Media Group, Jakarta.

Adonia Ivone Laturette, 2011, Hak Ulayat

dalam Hukum Tanah Nasional

(Ringkasan Disertasi), UNAIR,

Surabaya.

Barda Nawawi Arief, 2001, Masalah

Penegakan Hukum dan Kebijakan

Penanggulangan Kejahatan, Citra

Aditya Bakti, Bandung.

Basuki Rekso Wibowo, 2005, Menyelesaikan
Sengketa Bisnis di Luar Pengadilan, Makalah disampaikan pada Pengukuhan Guru Besar dalam Bidang Ilmu Hukum, Fakultas Hukum Universitas Airlangga, Surabaya.

Lawrence M. Friedman, 1972, Legal Theory, Columbia University Press Hampstead, New York.

Laura Nader and J. Noyon-G.E. Langemeyer, 1954, Het Wetboek van Strafrecht, Arnhem: S.Gonda-Quint, Harry F. Todd JR, 1978, The Disputing Process Law In Ten societies, Columbia University Press, New York. 
Mahmud Marzuki, 2005, Peter, Penelitian Hukum, Prenada Media, Jakarta.

Romli Atmasasmita, 1996, Sistem Peradilan

Pidana: Perspektif Eksistensialisme dan Abolisionisme, Bina Cipta, Bandung.

Sudarto, 1983, Hukum Pidana dan Perkembangan Masyarakat: Kajian Terhadap Pembaharuan Hukum Pidana, Sinar Baru, Bandung.

Yahman, 2011, Karakteristik Wanprestasi dan Tindak Pidana Penipuan Yang Lahir Dari Hubungan Kontraktual, Prestasi Pustaka, Jakarta.

\section{Peraturan Perundang-undangan}

Undang-undang Nomor 39 Tahun 1999, adanya jaminan hukum dari negara atas perlindungan Hak Asasi Manusia di Indonesia atas warga negaranya.

Kitab Undang-undang Hukum Pidana (KUHAP).
Peraturan Pemerintah Nomor 27 Tahun 1983 tentang Pelaksanaan Kitab Undangundang Hukum Pidana (KUHAP).

Peraturan Pemerintah Nomor 23 Tahun 2010 tentang Izin Usaha Operasi Produksi Pertambangan.

\section{Surat Kabar}

Memo, 23 Maret 2011.

Jawa Post, 13 Maret 2011, Kasiyem-Karni Tersangkan Lukir Napi.

Pos Kupang, 6 Desember 2008.

\section{Naskah Internet}

Sumba News, Pemerintah Lalai dalam Menuntaskan Kasus-kasus Illegal Mining Labaong, http:// labaong.sumbawanews.com/pemer intahlalaidalammenuntaskankasuskasusillegalmininglabaong. 